\title{
Joanna Kos-Łabędowicz
}

\author{
Uniwersytet Ekonomiczny w Katowicach \\ Wydział Ekonomii \\ e-mail: joanna.kos@ue.katowice.pl
}

\section{Działania promocyjne związane z koncepcją zrównoważonej mobilności miejskiej}

Kody JEL: O18, R41

Słowa kluczowe: zrównoważona mobilność, transport miejski, promocja, Unia Europejska

Streszczenie. Wzrost populacji zamieszkującej obszary miejskie w Unii Europejskiej oraz koncentracja działalności gospodarczej na tych obszarach stawiają nowe wyzwania w obszarze transportu miejskiego i mobilności. Koncepcja zrównoważonej mobilności miejskiej zakłada modelowanie miejskiego systemu transportowego zgodnie z założeniami zrównoważonego rozwoju. Zalecenia dotyczące mobilności miejskiej, wynikające z dokumentów Unii Europejskiej, wymagają wielu działań, w tym związanych z promocją pożądanych zachowań transportowych mieszkańców obszarów miejskich. Działania promocyjne są niezbędnym narzędziem budującym akceptację społeczną dla wprowadzanych zmian oraz angażującym i zachęcającym mieszkańców do współtworzenia systemu transportu miejskiego zgodnego z koncepcją zrównoważonej mobilności.

\section{Wprowadzenie}

$\mathrm{Na}$ obszarach miejskich mieszka prawie 3/4 mieszkańców Unii Europejskiej (72,4\% wszystkich mieszkańców) (European Commission, 2015). Urbanizacja w Unii Europejskiej postępuje zarówno przez zwiększanie się populacji zamieszkującej tereny miejskie, jak i powiększanie obszaru samych terenów miejskich oraz zacieranie się granic między obszarami zurbanizowanymi a wiejskimi (EEA, 2017). Należy podkreślić, że to właśnie w miastach koncentruje się działalność 
gospodarcza, kulturalna, społeczna i edukacyjna, a mieszkańcy obszarów miejskich mają określone oczekiwania względem możliwości przemieszczania się pomiędzy określonymi lokalizacjami. Żadne zatem miasto nie może funkcjonować bez sprawnej sieci transportu miejskiego, która umożliwiałaby mieszkańcom swobodne przemieszczanie się między różnymi punktami docelowymi.

Uwzględniając wiele zmian w otoczeniu miejskim (takich jak, np. wspominane procesy urbanizacji, oczekiwania mieszkańców, wpływ na środowisko) Unia Europejska w ostatnich latach zaczyna wyznaczać nowe kierunki rozwoju systemu transportu miejskiego zgodnie z koncepcją zrównoważonego rozwoju miejskiego. Koncepcja zrównoważonej mobilności miejskiej kompleksowo określa, jakie działania należy podjąć w celu umożliwienia mieszkańcom obszarów miejskich swobody przemieszczania się między wybranymi punktami docelowymi przy jednoczesnym ograniczaniu wpływu systemu transportu miejskiego na otoczenie. Działania związane z zapewnieniem zrównoważonej mobilności miejskiej dotyczą różnych aspektów systemu transportu miejskiego, zarówno infrastruktury, środków transportu, jak i samych uczestników/mieszkańców.

Celem artykułu jest przybliżenie koncepcji zrównoważonej mobilności miejskiej zgodnej z zaleceniami Unii Europejskiej, a w szczególności podejmowanych działań promujących zmianę zachowań wśród mieszkańców obszarów miejskich. Przeanalizowano unijne dokumenty związane z koncepcją zrównoważonej mobilności miejskiej oraz opracowania naukowe z tego zakresu. Dodatkowo przedstawiono realizowane inicjatywy promujące koncepcję zrównoważonej mobilności na przykładzie Krakowa.

Analiza unijnych dokumentów dotyczących zapewniania zrównoważonej mobilności miejskiej oraz opisany przykład działań promujących, prowadzonych przez miasto Kraków, wskazują na wysoki poziom współzależności opisywanych działań. Działania zmierzające do zapewnienia zrównoważonej mobilności dotyczą wielu aspektów systemu transportu miejskiego oraz wymagają zmian i dostosowania wszystkich użytkowników do tego systemu. Działania promocyjne są niezbędnym narzędziem budującym akceptację społeczną dla wprowadzanych zmian oraz angażującym i zachęcającym mieszkańców do współtworzenia takiego systemu transportu miejskiego, jaki najlepiej spełni ich potrzeby przy zachowaniu postulatu o ograniczaniu wpływu na otoczenie i poprawie jakości życia w mieście.

\section{Zrównoważona mobilność miejska}

Rozwój zrównoważonej mobilności na terenach miejskich ma sprzyjać rozwojowi gospodarczemu, wzrostowi zatrudnienia oraz integracji społecznej, co jest zgodne z ogólnym celem Strategii Europa 2020 (European Commission, 2014). Duże znaczenie ma również promowanie środków transportu przyjaznych środo- 
wisku oraz próby zmiany zachowań i preferencji mieszkańców odnośnie do wykorzystywanych środków transportu. Do wyzwań stojących przed transportem miejskim związanych z mobilnością zalicza się: kongestię i problem z parkowaniem, dłuższe przejazdy, niedostosowany do potrzeb zbiorowy transport publiczny, utrudnienia dla transportu niezmotoryzowanego, utrata przestrzeni publicznej, wysokie koszty utrzymania, wpływ na środowisko i zużycie energii, wypadki i bezpieczeństwo uczestników ruchu, zagospodarowanie przestrzenne, przewozy towarowe w obszarze miejskim (Rodrigue, Comtois, Slack, 2017). $\mathrm{W}$ tabeli 1 przedstawiono wyzwania związane z zapewnieniem mobilności miejskiej, potencjalne rozwiązania zidentyfikowanych wyzwań oraz wzajemne powiązania (Wefering, Rupprecht, Bührmann, Böhler-Baedeker, 2014).

Tabela 1

Mobilność miejska - wyzwania, potencjalne rozwiązania oraz zależności między nimi

\begin{tabular}{|l|c|c|c|c|c|c|}
\hline \multirow{2}{*}{ Rozwiązania } & \multicolumn{5}{|c|}{ Wyzwania } \\
\cline { 2 - 7 } & $\begin{array}{c}\text { zdro- } \\
\text { wie }\end{array}$ & $\begin{array}{c}\text { kon- } \\
\text { gestia }\end{array}$ & $\begin{array}{c}\text { bezpieczen- } \\
\text { stwo } \\
\text { i ochrona }\end{array}$ & $\begin{array}{c}\text { udział } \\
\text { społeczny }\end{array}$ & $\begin{array}{c}\text { planowa- } \\
\text { nie strate- } \\
\text { giczne }\end{array}$ & $\begin{array}{c}\text { globalne } \\
\text { zmiany kli- } \\
\text { matu }\end{array}$ \\
\hline $\begin{array}{l}\text { Czyste paliwa } \\
\text { i pojazdy }\end{array}$ & ++++ & + & + & + & ++ & +++ \\
\hline $\begin{array}{l}\text { Transport ładun- } \\
\text { ków }\end{array}$ & ++++ & +++ & +++ & +++ & +++ & ++ \\
\hline $\begin{array}{l}\text { Strategie zarzą- } \\
\text { dzania popytem }\end{array}$ & ++++ & ++++ & ++ & ++++ & +++ & +++ \\
\hline $\begin{array}{l}\text { Zarządzanie } \\
\text { mobilnością }\end{array}$ & ++ & ++++ & + & ++++ & +++ & +++ \\
\hline $\begin{array}{l}\text { Transport } \\
\text { zbiorowy }\end{array}$ & ++ & +++ & ++++ & +++ & +++ & ++ \\
\hline $\begin{array}{l}\text { Telematyka } \\
\text { w transporcie }\end{array}$ & + & ++++ & +++ & + & + & ++ \\
\hline $\begin{array}{l}\text { Opcje mobilności } \\
\text { mniej zależne od } \\
\text { samochodu }\end{array}$ & +++ & +++ & ++++ & ++++ & +++ & +++ \\
\hline $\begin{array}{l}\text { Plany Zrówno- } \\
\text { ważonej Mobil- } \\
\text { ności Miejskiej }\end{array}$ & +++ & ++++ & ++++ & ++++ & ++++ & ++ \\
\hline
\end{tabular}

Źródło: Wefering, Rupprecht, Bührmann, Böhler-Baedeker, 2014.

W koncepcji zapewniania zrównoważonej mobilności miejskiej kluczowe jest stworzenie takiego systemu przemieszczania na obszarze miejskim, który równocześnie pozwoli na zwiększenie dostępności poszczególnych obszarów i usług (pobudzając lokalną gospodarkę) oraz przyczyni się do poprawy jakości życia mieszkańców i stanu środowiska naturalnego. Należy przy tym zwrócić uwagę, że zarówno infrastruktura, jak i środki transportu (będące integralnymi częściami składowymi systemu transportu miejskiego) pełnią rolę narzędzi 
umożliwiających przemieszczanie, a nie elementów kreujących mobilność. Zmiana w podejściu do planowania systemu transportu miejskiego na rzecz zarządzania mobilnością wynika po części z zauważalnej nieefektywności inwestycji w infrastrukturę mimo wysokich finansowych i społecznych kosztów tego typu działań. Pomimo powszechnego przekonania o konieczności rozbudowy infrastruktury jako środka na ograniczenie kongestii i zwiększenia przepustowości coraz więcej wskazuje na błędność tego założenia (Schwartz, 2015).

Transport miejski jest ważnym elementem wspólnej sieci transportowej, jednak w większości przypadków pozostaje w gestii lokalnych instytucji odpowiadających za jego kształtowanie na terenie danego miasta albo aglomeracji. Rosnące wymagania względem mobilności na obszarach miejskich są przedmiotem zainteresowania na szczeblu Unii Europejskiej już od lat 90. XX wieku, ze szczególnym uwzględnieniem Planu dziatania na rzecz mobilności w miastach (Komisja Europejska, 2009) oraz komunikatu Wspólne dązenie do osiagnięcia konkurencyjnej i zasobooszczędnej mobilności w miastach (Komisja Europejska, 2013) oferujące wsparcie dla kształtowania zbieżnej polityki odnoszącej się do mobilności przez poszczególne jednostki na poziomie lokalnym oraz wykorzystywania Inteligentnych Systemów Transportowych w transporcie miejskim.

Kreowanie zrównoważonej mobilności wymaga realizacji działań w różnych sferach rozwoju miasta oraz społeczeństwa, często wykraczających poza sam obszar transportowy. W tabeli 2 zaprezentowano różnice między tradycyjnym planowaniem transportu a planowaniem zrównoważonej mobilności miejskiej (Wefering i in., 2014). Działania należy podejmować tak, aby kreując system transportu miejskiego w efektywny sposób wykorzystywać wszystkie dostępne zasoby jednocześnie, promując ekologiczne i energooszczędne formy przemieszczania. Planowane inwestycje (również infrastrukturalne) powinny być nakierowane na zwiększenie dostępności najważniejszych celów podróży przy zachowaniu zasady zrównoważonego rozwoju.

Tabela 2

Różnice między tradycyjnym planowaniem transportu

a planowaniem zrównoważonej mobilności miejskiej

\begin{tabular}{|l|l|l|}
\hline \multicolumn{1}{|c|}{ Kryteria } & $\begin{array}{l}\text { Tradycyjne plano- } \\
\text { wanie transportu }\end{array}$ & \multicolumn{1}{|c|}{ Planowanie zrównoważonej mobilności miejskiej } \\
\hline $\begin{array}{l}\text { Przedmiot } \\
\text { uwagi }\end{array}$ & $\begin{array}{l}\text { skoncentrowane } \\
\text { na ruchu }\end{array}$ & skoncentrowane na ludziach \\
\hline \multirow{4}{*}{$\begin{array}{l}\text { Najważniejsze } \\
\text { cele }\end{array}$} & $\begin{array}{l}\text { płynność i pręd- } \\
\text { kość ruchu }\end{array}$ & $\begin{array}{l}\text { dostępność i jakość życia, zrównoważenie, jakość } \\
\text { gospodarki, równość społeczna, zdrowie oraz jakość } \\
\text { środowiska }\end{array}$ \\
\cline { 2 - 3 } & $\begin{array}{l}\text { skoncentrowanie } \\
\text { na środkach trans- } \\
\text { portu }\end{array}$ & $\begin{array}{l}\text { zbilansowany rozwój wszystkich właściwych środ- } \\
\text { ków transportu i przejście w kierunku bardziej eko- } \\
\text { logicznych i zrównoważonych środków transportu }\end{array}$ \\
\cline { 2 - 4 } & $\begin{array}{l}\text { skoncentrowanie } \\
\text { na infrastrukturze }\end{array}$ & $\begin{array}{l}\text { zintegrowany zestaw działań dla osiągnięcia efek- } \\
\text { tywnych kosztowo rozwiązań }\end{array}$ \\
\hline
\end{tabular}


Działania promocyjne związane z koncepcją zrównoważonej mobilności...

\begin{tabular}{|l|l|l|}
\hline $\begin{array}{l}\text { Rodzaj } \\
\text { dokumentu }\end{array}$ & $\begin{array}{l}\text { sektorowy doku- } \\
\text { ment planistyczny }\end{array}$ & $\begin{array}{l}\text { sektorowy dokument planistyczny, który jest spójny } \\
\text { i komplementarny z powiązanymi obszarami polityki } \\
\text { rozwoju }\end{array}$ \\
\hline $\begin{array}{l}\text { Okres } \\
\text { planowania }\end{array}$ & $\begin{array}{l}\text { krótko- i średnioo- } \\
\text { kresowy }\end{array}$ & $\begin{array}{l}\text { krótko- i średniookresowy plan wpisany w długoter- } \\
\text { minową wizję i strategię }\end{array}$ \\
\hline Zasięg & $\begin{array}{l}\text { w odniesieniu do } \\
\text { granic administra- } \\
\text { cyjnych }\end{array}$ & $\begin{array}{l}\text { powiązanie z obszarem funkcjonalnym bazującym } \\
\text { na dojazdach do pracy }\end{array}$ \\
\hline $\begin{array}{l}\text { Przygotowany } \\
\text { przez: }\end{array}$ & inżynierów ruchu & interdyscyplinarne zespoły planistyczne \\
\hline $\begin{array}{l}\text { Planowany } \\
\text { przez: }\end{array}$ & ekspertów & $\begin{array}{l}\text { z udziałem interesariuszy z wykorzystaniem przej- } \\
\text { rzystego i opartego na konsultacjach podejścia }\end{array}$ \\
\hline Kontrola & $\begin{array}{l}\text { ograniczona ocena } \\
\text { wpływu }\end{array}$ & $\begin{array}{l}\text { regularne monitorowanie i ocena wpływu na po- } \\
\text { trzeby wyciągania wniosków i poprawy procesu }\end{array}$ \\
\hline
\end{tabular}

Źródło: opracowano na podstawie Wefering i in., 2014.

Mimo wytycznych zaprezentowanych w tabeli 2, poziom i zakres zaawansowania działań związanych z planowaniem i wdrażaniem zrównoważonej mobilności miejskiej różni się znacząco między poszczególnymi państwami członkowskimi (Eltis, 2017). Przykładowo, w Polsce w ustawie o publicznym transporcie zbiorowym (Ustawa..., 2011) wskazuje się na konieczność opracowania i uchwalenia planu zrównoważonego rozwoju transportu publicznego dla gmin liczących powyżej 50 tys. mieszkańców i powiatów o liczbie przekraczającej 80 tys. Podobnie jak w tradycyjnym planowaniu transportu, plan zrównoważonego rozwoju transportu publicznego różni się zakresowo od planu zrównoważonej mobilności miejskiej (Wołek, 2015). Wszelkie decyzje związane z planowaniem i rozwojem zrównoważonego miejskiego systemu transportowego są nadzwyczaj skomplikowane, ponieważ wymagają uwzględnienia wielu czynników i kryteriów, które niejednokrotnie są ze sobą sprzeczne (np. kompromis między dostępnością a minimalizacją negatywnego wpływu na środowisko i społeczeństwo) (Sindakis, Depeige, Anoyrkati, 2015). Niebanalnym problemem mogącym się pojawić na różnych etapach podejmowanych działań jest zmiana priorytetu poszczególnych kryteriów, szczególnie jeżeli okres realizacji jest wydłużony, np. przyznanie większej wagi kryteriom środowiskowym w fazie planowania, by następnie oceniając wdrożenie, podkreślać znaczenie kryteriów społecznych i na tej podstawie oceniać skuteczność podjętych działań (Brorström, 2015).

\section{Działania zmierzające do zapewnienia zrównoważonej mobilności miejskiej}

Działania związane z zapewnianiem zrównoważonej mobilności miejskiej z jednej strony mają zwiększyć efektywność systemu transportowego przez lepsze wykorzystanie istniejącej infrastruktury, a z drugiej ograniczyć szkodliwe efekty dla społeczności i środowiska. Poważnym czynnikiem przyczyniającym się do 
powstawania szkodliwych efektów (takich jak hałas, spaliny, kongestia) jest powszechne wykorzystywanie prywatnych samochodów, stąd wiele z podejmowanych na szczeblu lokalnym działań ma skłonić mieszkańców do ograniczenia korzystania z nich. Działania te mogą przyjmować różne formy albo zniechęcać do korzystanie z samochodów przez stosowanie odpowiednich regulacji, polityki opłat czy fizycznego planowania infrastruktury (np. strefy wyciszonego ruchu) albo promować wśród mieszkańców wykorzystywanie niezmotoryzowanych, aktywnych form transportu (Saliara, 2014). Badania wykazują, że najefektywniejsze jest równoczesne stosowanie obu typów działań: jeżeli zniechęcanie do korzystania z samochodu ma odnieść sukces, konieczne jest zapewnienie odpowiedniego substytutu pozwalającego na odbycie całej zaplanowanej podróży, albo w ostateczności na umożliwienie płynnej zmiany na inny środek transportu na pewną jej część (Şimşekoğlu, Nordfjærn, Rundmo, 2015).

Warto nadmienić, że bardzo wiele rozwiązań zwiększających zrównoważoną mobilność miejską i podnoszących efektywność miejskiego systemu transportowego funkcjonuje na podstawie nowoczesnych technologii informacyjno-komunikacyjnych (ang. ICT). Wymienienie tylko najpopularniejszych, czyli np. carsharing, bikesharing, zintegrowane zarządzanie opłatami, zarządzanie ruchem w czasie rzeczywistym, informacja pasażerska w czasie rzeczywistym czy aplikacje mobilne wspomagające podejmowanie decyzji przez pasażerów, pozwala stwierdzić, że ICT stały się stałym i niezbędnym elementem miejskiego systemu transportowego (Kos-Łabędowicz, 2016).

Działania związane z zapewnieniem zrównoważonej mobilności w miastach przy jednoczesnym zmniejszeniu negatywnych oddziaływań transportu coraz częściej znajdują się w polu zainteresowania zarówno naukowców, jak i polityków szczebla unijnego i lokalnego. Niestety badania przeprowadzone w ramach Eurobarometru 406 dotyczące postaw mieszkańców Unii Europejskiej wskazują, że podejmowanie działań zmierzających do zapewnienia zrównoważonej mobilności miejskiej nie będzie wcale takie proste. W tabeli 3 wskazano najważniejsze wyniki Eurobarometru dotyczące mobilności miejskiej (European Commission, 2013).

Tabela 3

Główne wyniki Eurobarometru 406 dotyczącego postaw Europejczyków w kwestii mobilności miejskiej

\begin{tabular}{|c|l|l|}
\hline Procent & \multicolumn{1}{|c|}{ Wyniki } & \multicolumn{1}{|c|}{ Perspektywa } \\
\hline 50 & Europejczyków korzysta codziennie z samochodu & zagrożenie \\
\hline 38 & $\begin{array}{l}\text { Europejczyków napotyka problem podczas podróżowania w ob- } \\
\text { rębie miast }\end{array}$ & zagrożenie \\
\hline & $\begin{array}{l}\text { Europejczyków uważa, że: } \\
81\end{array}$ & szansa \\
76 & - zanieczyszczenie powietrza & \\
74 & - koszty transportu & \\
\hline
\end{tabular}


Działania promocyjne związane z koncepcją zrównoważonej mobilności...

\begin{tabular}{|c|l|l|}
\hline 73 & - wypadki & \\
72 & - hałas & \\
& są poważnymi problemami na obszarach miejskich & \\
\hline 56 & Europejczyków uważa, że: & szansa \\
59 & - lepszy publiczny transport miejski & \\
& $\begin{array}{l}\text { są najlepszzym sposobem na usprawnienie transportu na obsza- } \\
\text { rach miejskich }\end{array}$ & \\
\hline 37 & $\begin{array}{l}\text { Europejczyków uważa że sytuacja w zakresie ruchu miejskiego } \\
\text { będzie ulegać pogorszeniu }\end{array}$ & $\begin{array}{l}\text { zagrożenie } \\
\text { szansa }\end{array}$ \\
\hline
\end{tabular}

Źródło: opracowano na podstawie European Commision, 2013.

Z przedstawionych wyników jasno wynika, że po pierwsze obywatele Unii Europejskiej nie wykazują szczególnego optymizmu w kwestii funkcjonowania systemu transportu miejskiego oraz po drugie, iż są świadomi zarówno problemów, jak i potencjalnych rozwiązań mogących poprawić aktualny stan.

Istotne znaczenie dla stworzenia warunków sprzyjających kreacji zrównoważonej mobilności miejskiej ma uwzględnienie i zaangażowanie wszystkich grup interesariuszy, a w szczególności mieszkańców, którzy na co dzień korzystają z systemu transportu miejskiego i to ich decyzje będą miały decydujące znaczenie w kwestii powodzenia lub porażki podjętych działań (Gabrielli, 2014). Mieszkańcy będący użytkownikami miejskiego systemu transportowego muszą być świadomi, jak podejmowane przez nich decyzje dotyczące wyboru trasy i sposobu przemieszczania się w mieście wpływają na otoczenie i jakość życia w mieście. Kluczowe jest prowadzenie działań edukacyjnych i promocyjnych, mogących potencjalnie wpłynąć na zmianę zachowań i nawyków transportowych poszczególnych mieszkańców ze szczególnym promowaniem publicznego transportu zbiorowego oraz aktywnych form transportu.

\section{Promowanie zrównoważonej mobilności miejskiej}

Działania związane z promowaniem zrównoważonej mobilności miejskiej pozostają w gestii poszczególnych miast i muszą być dostosowane do ogółu podejmowanych działań. Niemniej powołana w 2002 roku przez Komisję Europejską Inicjatywa CIVITAS umożliwia miastom pozyskanie wsparcia (finansowego i kompetencyjnego) w realizacji działań na rzecz zrównoważonego rozwoju na obszarach miejskich. W ramach inicjatywy podejmowane są długofalowe działania na rzecz rozwoju zrównoważonej mobilności w danym mieście, w następujących obszarach: ekologiczne paliwa i pojazdy, zbiorowy transport publiczny, strategie zarządzania natężeniem ruchu, zarządzanie mobilnością, bezpieczeństwo, nieuzależniony od samochodu styl życia, logistyka towarowych przewozów miejskich, systemy telematyczne w transporcie, plany zrównoważonej mobilności miejskiej (CIVITAS, 2013). 
W ramach inicjatywy wspierane są również kampanie informacyjne i promocyjne. Przykładowe działania, korzyści dla poszczególnych grup docelowych, oraz czynniki potencjalnie wpływające na sukces prowadzonych działań promujących przedstawiono w tabeli 4.

Tabela 4

Różnice między tradycyjnym planowaniem transportu a planowaniem zrównoważonej mobilności miejskiej

\begin{tabular}{|c|c|}
\hline Kryteria & Aspekty \\
\hline $\begin{array}{l}\text { Dostępne } \\
\text { działania }\end{array}$ & $\begin{array}{ll}- & \text { zintegrowane strategie informacyjne } \\
- & \text { kampanie promocyjne i marketingowe zrównoważonych środków trans- } \\
\text { portu } & \\
\text { organizacja imprez i wydarzeń wzmacniających wizerunek komunikacji } \\
\text { zbiorowej }\end{array}$ \\
\hline Korzyści & 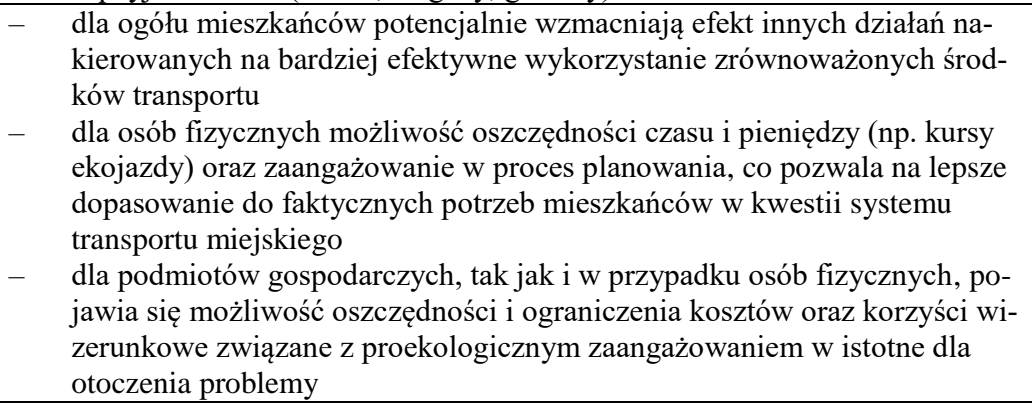 \\
\hline $\begin{array}{l}\text { Czynniki } \\
\text { sukcesu }\end{array}$ & $\begin{array}{ll}- & \text { zapewnienie wsparcia politycznego oraz funduszy } \\
\text { - } & \text { większa akceptacja społeczna dla „miękkich” działań } \\
\text { - } & \text { organizacja działań umożliwiająca włączenie mieszkańców }\end{array}$ \\
\hline
\end{tabular}

Źródło: opracowano na podstawie CIVITAS, 2010.

Przykładem miasta prowadzącego kompleksowe działania na rzecz zrównoważonej mobilności miejskiej (w tym działania informacyjne i promocyjne) jest Kraków. Jest to jedno z najstarszych miast w Polsce - atrakcyjny cel turystyczny oraz ważny ośrodek gospodarczy, kulturowy i naukowy. Mimo rozwiniętego zbiorowego transportu publicznego, w ostatnich latach, tak jak i w wielu miastach w środkowej i Centralnej Europie zauważalny jest rosnący trend związany z częstszym wykorzystywaniem prywatnych samochodów (CIVITAS, 2017). W aktualnej Polityce Transportowej rozwój i promowanie ekologicznych form podróżowania zostało przyjęte jako II cel główny i przewiduje działania związane z promocją aktywnych form transportu (rowerowego i pieszego), transportu zbiorowego oraz kształtowaniem ,świadomości dotyczącej konieczności realizacji 
koncepcji zarządzania mobilnością" (cel szczegółowy II.4) (Rada Miasta Kraków, 2016). Działania związane z tworzeniem nowej kultury mobilności są skierowane na zmianę przyzwyczajeń transportowych i racjonalizację wyboru środków podróży.

Należy podkreślić, że działania promujące zrównoważoną mobilność miejską przez miasto Kraków są prowadzone od dawna, w sposób kompleksowy i ukierunkowany na różne grupy docelowe. Sztandarowym wydarzeniem promującym zrównoważoną mobilność jest udział miasta w Europejskim Tygodniu Zrównoważonej Mobilności (po raz 17. w 2016 r.) oraz Europejskim Dniu bez Samochodu (po raz 15. w 2016 r.). Ostatni ETZM w Krakowie odbył się w dniach 16-22 września 2016 roku pod hasłem „Zrównoważony transport. Silna gospodarka”. W ramach programu odbyło się wiele spotkań, warsztatów, szkoleń, konkursów oraz pokazów skierowanych do różnych grup docelowych (poczynając od najmłodszych). Udostępniono do zwiedzania wiele obiektów związanych $\mathrm{z}$ transportem miejskim (np. uruchomiono zabytkowe i historyczne linie tramwajowe), przygotowano specjalne trasy rowerowe, wprowadzono tymczasowe zmiany w organizacji ruchu (pilotażowe rozwiązania na wybranych odcinkach) i wiele innych atrakcji. Bogata oferta atrakcyjnych wydarzeń promująca zarówno aktywne formy transportu, jak i publiczny transport zbiorowy wpisuje się w działania związane z promocją zrównoważonej mobilności miejskiej (Eko Centrum, 2016). Należy przy tym podkreślić, że ETZM jest tylko jednym z wielu działań promujących zrównoważoną mobilność na terenie Krakowa, praktycznie cały czas są podejmowane działania, np.:

a) kampania „Kraków. Mobilność aktywna”, hasła np.: „Pieszo po zdrowie”, „Dzięki, że wybierasz rower!”, obejmująca plakaty na przystankach, emisje spotów w pojazdach komunikacji miejskiej, ulotki, kalendarze (Otwarty Plan, 2016);

b) udział w Europejskiej Rywalizacji Rowerowej (1-31.05.2017 r.) pod hasłem „\#Kręćże dla Krakowa”, zachęcający mieszkańców do indywidualnych i grupowych dojazdów rowerem do szkół i pracy (16. miejsce dla Krakowa na 52 uczestniczące miasta) (European Cycling Challange, 2017).

Dobrym wyznacznikiem zaangażowania miasta Kraków w podejmowanie działań związanych z zapewnianiem zrównoważonej mobilności dla swoich mieszkańców jest otrzymana w 2016 roku nagroda przyznana przez CIVITAS uznająca Kraków jako jedno z najlepszych europejskich miast faktycznie poprawiających jakość życia dla swoich mieszkańców (Nagroda ..., 2016). 


\section{Podsumowanie}

Do działań wskazywanych zarówno w unijnych dokumentach, jak i przez środowisko naukowe zalicza się cztery następujące obszary: wykorzystywanie nowoczesnych technologii, dostosowanie regulacji i kosztów, tak żeby uwzględniały zewnętrzne koszty transportu, zintegrowanie planowania przestrzennego z polityką transportową, zapewnienie społecznej akceptacji rozwiązań mających zapewnić zrównoważoną mobilność miejską (Banister, 2008). Działania te powinny być podejmowane równocześnie i z uwzględnieniem wzajemnych powiązań i wpływów. Brak kompleksowego podejścia do kwestii zapewniania zrównoważonej mobilności na obszarach miejskich będzie wpływał na ograniczoną skuteczność podejmowanych działań. Bardzo istotne z punktu widzenia skuteczności prowadzonych działań jest uzyskanie akceptacji społecznej co do znaczenia zrównoważonej mobilności dla poprawy jakości życia oraz rozwoju gospodarczego i społecznego na obszarze miejskim.

Zapewnieniu akceptacji społecznej służą wszelkie działania informacyjne, promocyjne i edukacyjne. Zmiana mentalności i kształtowanie świadomości odnośnie do zrównoważonej mobilności powinna być planowana w perspektywie długookresowej, z uwzględnieniem różnych grup docelowych, w tym zwłaszcza dzieci i młodzieży, jako grupy jeszcze nieprzyzwyczajonej do stylu życia, w którym ważną rolę odgrywa samochód. Należy również podkreślić, że działania promocyjne powinny być prowadzone w sposób ciągły i planowany długofalowo, a nie tylko przypadkowo i wybiórczo. Dobrym przykładem działań promujących zrównoważoną mobilność mogą być działania podejmowane przez miasto Kraków, które w ramach inicjatywy CIVITAS angażowało się w promocję zrównoważonego transportu jeszcze przed pojawieniem się w dokumentach unijnych wymogów odnośnie do zrównoważonej mobilności miejskiej. Działania podejmowane na terenie Krakowa mają charakter ciągły, są prowadzone wspólnie z innymi inicjatywami (np. promowanie transportu rowerowego połączone jest $\mathrm{z}$ zapewnianiem nowej infrastruktury rowerowej) oraz kierowane do różnych grup docelowych (dzieci, młodzieży i osób starszych dojeżdżających do pracy).

\section{Bibliografia}

Banister, D. (2008). The sustainable mobility paradigm. Transport Policy, 15 (2), 73-80. DOI:10.1016/j.tranpol.2007.10.005.

Brorström, S. (2015). Implementing innovative ideas in a city: good solutions on paper but not in practice? International Journal of Public Sector Management, 28 (3), 166-180. DOI: 10.1108/IJPSM-11-2014-0137.

CIVITAS (2010). Promowanie nowej kultury mobilności w miastach. Policy Advice Notes. Pobrano z: http://civitas.eu/sites/default/files/civitas_ii_policy_advice_notes_08_promotion_ and_education_pl.pdf (3.06.2017).

CIVITAS (2013). About Us. Pobrano z: http://civitas.eu/about-us-page (3.06.2017).

CIVITAS (2017). Kraków. Sustainable mobility marketing strategy. Pobrano z: http://civitas.eu/content/sustainable-mobility-marketing-strategy (3.06.2017). 
EEA (2017). Urban environment. European Environment Agency. Pobrano z: www.eea.europa.eu/ themes/urban/intro (30.05.2017).

Eko Centrum (2016). Europejski Tydzień Zrównoważonej Mobilności i Europejski Dzień bez Samochodu 16-22.09.2016 r. Centrum Edukacji Ekologicznej. Pobrano z: www.ekocentrum. krakow.pl/915,a,europejski-tydzien-zrownowazonej-mobilnosci-i-europejski-dzien-be.htm (3.06.2017).

Eltis (2017). Member State profiles. Eltis, The urban mobility observatory. Pobrano z: www.eltis.org/mobility-plans/member-state-profiles (6.05.2017).

European Commission (2013). Attitudes of Europeans towards urban mobility, Special Eurobarometer 406, Report. Pobrano z: http://ec.europa.eu/public_opinion/archives/ebs/ebs_406_ en.pdf 6.05.2017).

European Commission (2014). Taking stock of the Europe 2020 strategy for smart, sustainable and inclusive growth. COM(2014) 130 final/2. Pobrano z: http://ec.europa.eu/europe2020/pdf/ europe2020stocktaking_en.pdf (6.05.2017).

European Commission (2015). Eurostat regional yearbook 2015. Pobrano z: http://ec.europa.eu/eurostat/web/products-statistical-books/-/KS-HA-15-001 (30.05.2017).

European Cycling Challenge (2017). Główna tabela wyników. Edycja 2017. Pobrano z: http://www.cyclingchallenge.eu/pl/classifiche/classifica-principale/ (3.06.2017).

Gabrielli, S., Forbes, P., Jylhä, A., Wells, S., Sirén, M., Hemminki, S., Nurmi, P., Maimone, R., Masthoff, J., Jacucci, G. (2014). Design challenges in motivating change for sustainable urban mobility. Computers in Human Behavior, 41, 416-423. DOI:10.1016/j.chb.2014.05.026.

Komisja Europejska (2009). Plan działania na rzecz mobilności w miastach. COM (2009) 490 wersja ostateczna. Pobrano z: http://eur-lex.europa.eu/legal-content/PL/ALL/?uri=CELEX:520 10AE0767 (6.05.2017).

Komisja Europejska (2013). Wspólne dążenie do osiagnięcia konkurencyjnej i zasobooszczędnej mobilności w miastach COM (2013) 913 wersja ostateczna. Pobrano z: http://eur-lex.europa.eu/legal-content/PL/TXT/?uri=CELEX:52013DC0913 (8.05.2017).

Kos-Łabędowicz, J. (2016). ICT and the future of urban transportation. European perspective. W: J. Mikulski (red.), Challenge of Transport Telematics. TST 2016. Communications in Computer and Information Science, 640, 122-134, Springer. DOI:10.1007/978-3-31949646-7_11.

Nagroda CIVITAS 2016 (2016). Biuletyn Informacji Publicznej. Miasto Kraków. Pobrano z: https://www.bip.krakow.pl/?dok_id=79987\&metka=1 (3.06.2017).

Otwarty Plan (2016). Spoty Kampanii „Kraków. Mobilność Aktywna”. Fundacja Otwarty Plan. Pobrano z: http://otwartyplan.org/spoty-kampanii-krakow-mobilnosc-aktywna/ (3.06.2017).

Rada Miasta Kraków (2016). Polityka transportowa dla miasta Krakowa na lata 2016-2025. Uchwała nr XLVII/848/16 Rady Miasta Krakowa z dnia 8 czerwca 2016 r. w sprawie przyjęcia Polityki Transportowej dla Miasta Krakowa na lata 2016-2025. Pobrano z: https://www.bip.krakow.pl/?dok_id=167\&sub_dok_id=167\&sub=uchwala\&query=id\%3D 21510\%26typ\%3Du (3.06.2017).

Rodrigue, J-P, Comtois, C., Slack B. (2017). The geography of transport systems. Hofstra University, Department of Global Studies \& Geograph. Pobrano z: http://people.hofstra.edu/geotrans (6.05.2017).

Saliara, K. (2014). Public transport integration: the case study of Thessaloniki, Greece. Transport Research Procedia, 4, 535-552. DOI:10.1016/j.trpro.2014.11.041.

Schwartz, S. (2015). Street Smart. New York: Public Affairs.

Şimşekoğlu, Ö., Nordfjærn, T., Rundmo, T. (2015). The role of attitudes, transport priorities, and car use habit for travel mode use and intentions to use public transportation in an urban Norwegian public. Transport Policy, 42, 113-120. DOI:10.1016/j.tranpol.2015.05.019.

Sindakis, S., Depeige, A., Anoyrkati, E. (2015). Customer-centered knowledge management: challenges and implications for knowledge-based innovation in the public transport sector. Journal of Knowledge Management, 19 (3), 559-578. DOI: 10.1108/JKM-02-2015-0046. 
Ustawa o publicznym transporcie zbiorowym z 16 grudnia 2010 roku, Dz.U. 2011, nr 5, poz. 13.

Wefering, F., Rupprecht, S., Bührmann, S., Böhler-Baedeker, S. (2014). Wytyczne. Opracowanie i wdrożenie planu zrównoważonej mobilności miejskiej. Eltis, The urban mobility observatory. Pobrano z: www.eltis.org/sites/eltis/files/bump_guidelines_pl.pdf (05.2017).

Wołek, M. (2015). Planowanie zrównoważonej mobilności miejskiej w Polsce i w Europie. Technika Transportu Szynowego, 10 (259), 20-24.

\section{Promotional Activities Related to the Concept of Sustainable Urban Mobility}

Keywords: sustainable mobility, urban transport, promotion, European Union

Summary. The growth of populations living in urban areas in the European Union and at the same time the increasing concentration of economic activity in these areas pose new challenges in the area of urban transport and mobility. The concept of sustainable urban mobility requires that the urban transport system will be planned according to the assumptions of sustainable development. Urban mobility recommendations, as documented by the European Union, require a range of actions, including the promotion of desirable transport behaviors of urban dwellers. Promotional activities are an important tool for building social acceptance for change and involve and encourage residents to contribute to a sustainable urban transport system development.

Translated by Joanna Kos-Labędowicz

\section{Cytowanie}

Kos-Łabędowicz, J. (2017). Działania promocyjne związane z koncepcją zrównoważonej mobilności miejskiej. Marketing i Zarządzanie, 1 (47), 131-142. DOI: 10.18276/miz.2017.47-12. 